\title{
MOBILITY AND DISTRIBUTION OF WHEY SOLUTIONS IN SOIL COLUMNS
}

\author{
MOBILIDADE E DISTRIBIÇÃO DE SOLUTOS DE SORO DE LEITE EM COLUNAS \\ DE SOLO
}

\begin{abstract}
Nara Cristina de Lima SILVA'; Hugo Alberto RUIZ²; Leandro da Silva ALMEIDA ${ }^{3}$
1. Professora do Ensino Básico, Técnico e Tecnológico do Instituto Federal do Triângulo Mineiro, Campus Uberlândia - IFTM, Uberlândia, MG, Brasil. nara.lima@iftm.edu.br; 2. Professor Voluntário da Universidade Federal de Viçosa, Departamento de Solos, Campus Viçosa, Viçosa, MG, Brasil; 3. Doutorando do Programa de Pós-Graduação em Agronomia na Universidade Federal de Uberlândia, Uberlândia, MG, Brasil. almeidalean26@gmail.com
\end{abstract}

\begin{abstract}
In Brazil's food industry, dairy production is one of the most important sectors, whose most relevant byproduct is whey. Due to the difficulties of reuse and environmental impacts caused when discarded as effluent in water bodies, an alternative for its final destination would be the application of this residue in the soil. The purpose of this study was to determine chemical changes and mobility and distribution of solutes in the soil after applications of whey rates, as well as to analyze the leachate collected after each application. The test was carried out in a laboratory, in PVC columns filled with soil. The treatments consisted of $2 \times 2$ samples of a typical dystrophic RedYellow Oxisol (Oxisol) and a typical dystrophic fluvic Inceptisol (Inceptisol), sampled in the layers 0- 20 and 20-40 $\mathrm{cm}$. Each experimental unit consisted of $11 \mathrm{PVC}$ rings (diameter of $6.6 \mathrm{~cm}$, height of $7 \mathrm{~cm}$ ). The columns were arranged in a randomized complete block design with five replications. Four whey rates were applied, corresponding to a soil pore volume of 0.2 , at intervals of six days. The leachate was collected 24 and 120 hours after each application to measure $\mathrm{pH}$, electrical conductivity (EC), chemical oxygen demand (COD), contents of total $\mathrm{N}, \mathrm{N}^{-\mathrm{NH}_{4}}{ }^{+}, \mathrm{N}^{-\mathrm{NO}_{3}}{ }^{-}, \mathrm{Na}$, $\mathrm{K}, \mathrm{Ca}$, and $\mathrm{Mg}$. Six days after the last whey application, the columns were opened and the soil of each ring was analyzed for $\mathrm{pH}, \mathrm{EC}$, total $\mathrm{N}, \mathrm{N}-\mathrm{NH}_{4}{ }^{+}, \mathrm{N}_{-} \mathrm{NO}_{3}{ }^{-}, \mathrm{Na}, \mathrm{K}, \mathrm{Ca}$, and $\mathrm{Mg}$. The high electrolyte concentrations of whey

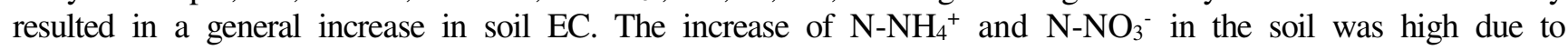
mineralization. High concentrations of $\mathrm{K}, \mathrm{Na}$ and $\mathrm{Ca}$ caused displacement of $\mathrm{Mg}$ from the exchange complex. It was concluded that from an environmental standpoint, whey soil application is a viable alternative, given that problems of salinization and leaching of undesirable elements are avoided by an adequate management.
\end{abstract}

KEYWORDS: Nitrogen mineralization. Leaching. Salinization.

\section{INTRODUCTION}

Whey consists of a milk co-product that is extracted from milk coagulation in the cheesemaking process (BRAZIL, 2013). This residue stands out due to the large volume generated (about $9 \mathrm{~L} \mathrm{~kg}^{-1}$ of cheese manufactured) and its quality characteristics, which allow several possibilities of use.

Whey represents approximately 80 to $90 \%$ of the milk volume and contains $55 \%$ of its nutrients, the water content varies from 91 to $95 \%$ (SILVA, 2006). Dry extract averages $6.9 \%$, of which $5 \%$ corresponds to lactose; $0.9 \%$ to proteins; $0.3 \%$ to lipids; and $0.1 \%$ to lactic acid, in addition to other nutrients present in lower concentrations (SANTOS, 2001).

The direct use of whey in human consumption includes its use mainly in the manufacture of dairy drinks and in the production of ricotta. The beneficiation processes allow the wide use of this residue in the manufacture of other products in the food industry and even in the pharmaceutical industry (MAHMOUD, 1994; BOUNOUS et al., 1999). However, the recovery of whey substances for such purposes depends on the availability of appropriate techniques and the use of economically viable processes.

Studies indicate potential use of whey in pig feed, mainly because of its high palatability and nutritional value. However, experimental studies indicate that whey can substitute up to $20 \%$ of the pig diet that are in the growing and finishing stages, without compromising performance and carcass characteristics (BERTOL et al., 1993).

As for cattle feeding, it is recommended that whey should not be substituted for milk at the stage of lactation and that it should be supplied in a limited way to adult animals. Some problems arising from the supply of whey to cattle are common, such as palatability drop after two days of storage due to souring. Diarrhea and tympanism can occur if animals consume large quantities of whey in a short period of time or if they are not consuming an adequate amount of whey (LIZIEIRE; CAMPOS, 2001).

The presence of proteins, lipids, mineral salts and lactose confers high polluting power to the whey 
when disposed without criteria in the environment (ROLFS et al., 2011). The treatment of whey as effluent in wastewater treatment plants is generally hampered due to the high daily volume and the high concentration of organic matter, ie high levels of biochemical oxygen demand (BOD), mainly due to the presence of lactose (MACHADO et al., 2001) Thus, most of the time, the destination given to this effluent is the disposal in the waterways.

Whey BOD varies from 30 to $60 \mathrm{~g} \mathrm{~L}^{-1}$, depending on the specific processing used in cheeses and lactose content (BRANDÃO, 1994). Therefore, the discharge of serum directly into watercourses leads mainly to the consumption of dissolved oxygen by microorganisms, and the mortality of fish and other individuals in the aquatic ecosystem may occur (ARAÚJO, 2001).

Given the above, studies become necessary to enable new forms of whey utilization. The disposition in the soil appears as an alternative when it is not possible to use this by-product in human or animal food.

In countries like the United States, the world leader in milk production, about $50 \%$ of whey is destined for human consumption. However, depending on locality and economic factors, $20 \%$ to $100 \%$ of this residue is used for the benefit of chemical and physical characteristics of the soil (ROBBINS; LEHRSCH, 1998).
The objective of this study was to determine chemical changes and the mobility and distribution of solutes after fractionated application of whey in columns filled with samples of a typical dystrophic Red-Yellow Oxisol (Oxisol) and a and a typical dystrophic fluvic Inceptisol (Inceptisol), withdrawn at two depths. In addition, the purpose of this study was to characterize the percolate from this application.

\section{MATERIAL AND METHODS}

In the laboratory, a test was carried out using soil columns in which whey percolation was performed. The treatments corresponded to a $2 \times 2$ factorial, being samples of a Oxisol and Inceptisol collected at two depths $(0-20$ and $20-40 \mathrm{~cm})$, in the municipality of Paula Cândido, Zona da Mata of Minas Gerais. The collection sites were selected among those with possibilities of receiving whey applications, considering that hillside areas, represented by Oxisol, and fluvial terraces used for pasture, represented by Inceptisol, are common in the region.

Samples of the 0-20 and 20-40 cm layers of these soil classes were collected air dried and sieved with $2 \mathrm{~mm}$ aperture for chemical and physical characterization (Table 1).

Table 1: Chemical and physical characterization of Oxisol and Inceptisol samples.

\begin{tabular}{|c|c|c|c|c|}
\hline \multirow{2}{*}{ Determination } & \multicolumn{2}{|c|}{ Oxisol } & \multicolumn{2}{|c|}{ Inceptisol } \\
\hline & $0-20 \mathrm{~cm}$ & $20-40 \mathrm{~cm}$ & $0-20 \mathrm{~cm}$ & $20-40 \mathrm{~cm}$ \\
\hline $\mathrm{pH}$ in water $(1: 2,5)$ & 5.23 & 4.90 & 6.05 & 5.75 \\
\hline $\mathrm{EC}(\mathrm{es})\left(\mathrm{mS} \mathrm{m}^{-1}\right)^{(1)}$ & 20.8 & 6.20 & 29.4 & 8.80 \\
\hline $\mathrm{N}$ total $\left(\mathrm{mg} \mathrm{dm}^{-3}\right)^{(3)}$ & 1570 & 980 & 1250 & 380 \\
\hline $\mathrm{K}\left(\mathrm{mg} \mathrm{dm}^{-3}\right)^{(5)}$ & 54 & 16 & 105 & 113 \\
\hline $\left.\mathrm{Na}(\mathrm{mg} \mathrm{dm})^{-3}\right)^{(5)}$ & 4.80 & 1.70 & 4.80 & 3.80 \\
\hline $\mathrm{Ca}^{2+}\left(\mathrm{cmol}_{\mathrm{c}} \mathrm{dm}^{-3}\right)^{(6)}$ & 1.30 & 0.38 & 2.47 & 1.18 \\
\hline $\mathrm{Mg}^{2+}\left(\mathrm{cmol}_{\mathrm{c}} \mathrm{dm}^{-3}\right)^{(6)}$ & 0.77 & 0.22 & 1.23 & 0.71 \\
\hline $\mathrm{Al}^{3+}\left(\mathrm{cmol}_{\mathrm{c}} \mathrm{dm}^{-3}\right)^{(7)}$ & 0.30 & 0.90 & 0 & 0.10 \\
\hline $\mathrm{P}\left(\mathrm{mg} \mathrm{dm}^{-3}\right)^{(8)}$ & 2.1 & 1.0 & 3.4 & 1.0 \\
\hline Organic matter $\left(\mathrm{g} \mathrm{kg}^{-1}\right)^{(9)}$ & 49.4 & 27.9 & 33.0 & 12.7 \\
\hline P remaining $\left(\mathrm{mg} \mathrm{L}^{-1}\right)^{(10)}$ & 28.30 & 20.20 & 44.70 & 34.50 \\
\hline \multicolumn{5}{|c|}{ Particle size analysis ${ }^{(11)}$} \\
\hline - Sand $\left(\mathrm{kg} \mathrm{kg}^{-1}\right)$ & 0.433 & 0.332 & 0.295 & 0.177 \\
\hline - Silt $\left(\mathrm{kg} \mathrm{kg}^{-1}\right)$ & 0.076 & 0.081 & 0.239 & 0.328 \\
\hline - Clay $\left(\mathrm{kg} \mathrm{kg}^{-1}\right)$ & 0.491 & 0.587 & 0.466 & 0.495 \\
\hline
\end{tabular}

(1) Electric conductivity in saturation paste extract (Richards, 1954). (2) Electrical conductivity in the 1:5 extract (Richards, 1954). (3) Modified Kjeldahl method (TEDESCO et al., 1985). (4) extractor KCl $1 \mathrm{~mol} \mathrm{~L}^{-1}$ (TEDESCO et al., 1995). (5) Mehlich-1 extractor (DEFELIPO; RIBEIRO, 1997). (6) $\mathrm{KCl}$ extractor $1 \mathrm{~mol} \mathrm{~L}^{-1}$ (Vettori, 1969). (7) $\mathrm{KCl}$ extractor $1 \mathrm{~mol} \mathrm{~L}^{-1}$ (Vettori, 1969). (8) Extractor Mehlich-1 (BRAGA; DEFELIPO, 1974). (9) Modified Walkley-Black method (DEFELIPO; RIBEIRO, 1997). (10) Alvarez V et al., (2000). (11) Ruiz (2005). 
Each experimental unit consisted of soil samples placed in $11 \mathrm{PVC}$ rings, $6.6 \mathrm{~cm}$ in diameter and $7 \mathrm{~cm}$ high, overlapped and sealed with silicone glue in the joints. At the lower end of the segment, a perforated PVC plug was fitted, with a funnel attached to it, employing plastic mass for sealing. On the last centimeter of the lower ring was placed a thin layer of glass wool and, over it, $1 \mathrm{~cm}$ of very thick sand (2.0-1.0 $\mathrm{mm})$, to facilitate drainage. Then another layer of glass wool was placed to avoid mixing the soil with the sand.

The inner walls of the rings received a layer of liquid resin on which was spread a mixture of washed coarse and fine sand in order to avoid preferential flow of water through the walls of the column. Externally, the rings were attached with adhesive tape, to mechanically stabilize the column, which was filled with soil up to $7 \mathrm{~cm}$ from the top edge, forming a column of $70 \mathrm{~cm}$ height and volume of $2.4 \mathrm{dm}^{3}$.
The soil, sieved by a $4 \mathrm{~mm}$ mesh, was placed with the help of a funnel, making circular movements to prevent the segregation of larger aggregates in the center of the column and, thus, changing the section of the infiltration. In addition, the column was slightly compacted, dropping it vertically from a height of approximately $0.5 \mathrm{~cm}$ from the ground three times, thus ensuring the desired soil volume $\left(2.4 \mathrm{dm}^{-3}\right)$.

In order to homogenize the humidity, the soil present in each experimental unit was saturated with deionized water 5 days before the beginning of the test, with the percolated volume discarded. After saturation, the upper end of the column was covered with plastic film to prevent water evaporation.

The treatments were arranged in a randomized complete block design with five replicates. The whey used in the experiment came from the manufacture of fresh minas cheese (Table 2).

Table 2. Physical, chemical and biochemical characterization of whey.

\begin{tabular}{|c|c|c|c|c|c|c|c|c|c|c|}
\hline $\mathrm{pH}^{1}$ & $\begin{array}{l}\mathrm{EC}^{2} \\
\mathrm{dS} \mathrm{m}^{-1}\end{array}$ & $\mathrm{BOD}^{3}$ & $\mathrm{COD}^{4}$ & $\mathrm{OG}^{5}$ & $\mathrm{ST}^{1}$ & Total $\mathrm{N}^{6}$ & $\mathrm{~K}^{7}$ & $\begin{array}{c}\mathrm{Na}^{7} \\
\mathrm{mg} \mathrm{L}^{-}\end{array}$ & $\mathrm{Ca}^{8}$ & $\mathrm{Mg}^{8}$ \\
\hline 4,73 & 6,12 & 37,93 & 68,11 & 3,01 & 67,59 & 1290 & 1656 & 456 & 555 & 75 \\
\hline
\end{tabular}

(1) APHA (1995). (2) Electric conductivity (EC) - APHA (1995). (3) Biochemical oxygen demand (BOD)- Winkler method (iodometric) (APHA, 1995). (4) Chemical oxygen demand (COD) - Open reflux method (APHA, 1995). (5) Oils and greases (OG) - Extraction method in Soxhlet (APHA, 1995). (6) Total nitrogen - Modified Kjeldahl method (TEDESCO et al., 1985). (7) Potassium (K) and sodium (Na) - Flame emission photometry. (8) Calcium (Ca) and magnesium (Mg)- Atomic absorption spectrophotometry.

The percolation columns containing the soil received four applications of 0.2 volume of pores of whey each at 6-day intervals. After 24 hours of each application, the percolate was collected and the volume determined. The percolate produced between 24 and 120 hours was also collected. Samples were duly stored under refrigeration for further analysis. The determination of percolates was performed by the modified Kjeldahl method (TEDESCO et al., 1997). With the percolated volume and the concentrations of $\mathrm{Na}, \mathrm{K}, \mathrm{Ca}$ and $\mathrm{Mg}$, total $\mathrm{N}, \mathrm{N}-\mathrm{NH}_{4}{ }^{+}, \mathrm{N}-\mathrm{NO}_{3}^{-}$, in the percolated solution, the lost amount of each solute was calculated by leaching.

After 6 days of the last application of whey, the columns were disassembled and the soil contained in the central $5 \mathrm{~cm}$ of each ring was removed for analysis. The results of the analyzes were as follows: $\mathrm{pH}$ in water, $\mathrm{EC}$ (1:5) (RICHARDS, 1954), total N, N-NH ${ }_{4}^{+}, \mathrm{N}^{-\mathrm{NO}_{3}}{ }^{-}$by the modified Kjeldahl method (TEDESCO et al., 1985), Na and K (DEFELIPO; RIBEIRO, 1997) and $\mathrm{Ca}$ and $\mathrm{Mg}$ (VETTORI, 1969).

The experimental results were analyzed statistically in order to verify the mobility and the distribution of the solutes in the columns of soil and the quantities in the percolated. The dependent variables were analyzed by means of orthogonal contrasts, to compare soil classes and sampling depths. The results were presented as mean contrasts (ALVAREZ V.; ALVAREZ, 2006). The values determined in the soil column rings were analyzed by regression, using the mean depth as the dependent variable.

\section{RESULTS AND DISCUSSION}

The conduction of the experiment in the confined environment of soil columns was complicated due to the appearance of colonies of fungi and bacteria that, together with the accumulation of fat, caused changes in the rate of infiltration in the different leaches. In an attempt to facilitate infiltration, scarification was performed on the upper ring, but the result was not satisfactory. As for leachate collection, there was a marked drop in volume during leaching. This, in fact, could have caused a mixture between the effluents of the last applications. The problems noted led to discarding the soil of the upper ring, submitted to scarification, and to consider only the two initial leaches in the presented results.

To determine the mobility and distribution of solutes in the soil columns, $\mathrm{pH}, \mathrm{EC}$ (1: 5), total 
$\mathrm{N}, \mathrm{N}-\mathrm{NH}_{4}{ }^{+}, \mathrm{N}-\mathrm{NO}_{3}{ }^{-}, \mathrm{K}, \mathrm{Na}, \mathrm{Ca}$ and $\mathrm{Mg}$ were related to the location of each ring. In order to determine regression equations, the dependent variables were analyzed by establishing the mean depth in the ring as an independent variable. Considering the $7 \mathrm{~cm}$ length of each ring and that determinations were performed on nine rings, the values of the independent variable were in the range of 3.5 to $59.5 \mathrm{~cm}$.
The application of whey in the studied soils caused a generalized decrease in $\mathrm{pH}$ (Table 1 and 3), a response consistent with the acidity of the applied residue (Table 2). The decrease was proportional to the values presented in the characterization (Table 1), registering lower $\mathrm{pH}$ in the Oxisol and the samples of the lower layers of the two soils under study.

Table 3: $\mathrm{pH}, \mathrm{EC}(1: 5)$, total $\mathrm{N}, \mathrm{N}-\mathrm{NH}_{4}{ }^{+}, \mathrm{N}^{-\mathrm{NO}_{3}}{ }^{-}, \mathrm{K}, \mathrm{Na}, \mathrm{Ca}$ and $\mathrm{Mg}$ according to the soil and the sampled layer after four whey leaches.

\begin{tabular}{|c|c|c|c|c|}
\hline \multirow{2}{*}{ Attribute } & \multicolumn{2}{|c|}{ Oxisol } & \multicolumn{2}{|c|}{ Inceptisol } \\
\hline & $0-20 \mathrm{~cm}$ & $20-40 \mathrm{~cm}$ & $0-20 \mathrm{~cm}$ & $20-40 \mathrm{~cm}$ \\
\hline $\mathrm{pH}$ & 4.75 & 4.36 & 5.19 & 4.44 \\
\hline $\operatorname{EC~}(1: 5)\left(\mathrm{mS} \mathrm{m}^{-1}\right)$ & 61.8 & 60.8 & 71.8 & 72.0 \\
\hline Total $\mathrm{N}\left(\mathrm{mg} \mathrm{dm}^{-3}\right)$ & 1997 & 1336 & 1681 & 689 \\
\hline $\mathrm{N}-\mathrm{NH}_{4}{ }^{+}\left(\mathrm{mg} \mathrm{dm}^{-3}\right)$ & 140 & 117 & 123 & 66 \\
\hline $\mathrm{N}-\mathrm{NO}_{3}-\left(\mathrm{mg} \mathrm{dm}^{-3}\right)$ & 64 & 74 & 61 & 57 \\
\hline $\mathrm{K}\left(\mathrm{mg} \mathrm{dm}^{-3}\right)$ & 568 & 567 & 611 & 601 \\
\hline $\mathrm{Na}\left(\mathrm{mg} \mathrm{dm}^{-3}\right)$ & 143 & 162 & 144 & 146 \\
\hline $\mathrm{Ca}\left(\mathrm{cmol}_{\mathrm{c}} \mathrm{dm}^{-3}\right)$ & 1.87 & 1.03 & 2.83 & 1.38 \\
\hline $\operatorname{Mg}\left(\mathrm{cmol}_{\mathrm{c}} \mathrm{dm}^{-3}\right)$ & 0.81 & 0.32 & 1.07 & 0.55 \\
\hline
\end{tabular}

The movement of the whey along the column led to a decrease in $\mathrm{pH}$ throughout the depth of the experimental unit (Figure 1). As previously indicated, to the acidity of the product, $\mathrm{pH} 4.73$ (Table 2), oxidation processes of organic matter were added which contributed to this decrease in $\mathrm{pH}$.

The incorporation of whey caused a generalized increase in EC of extract 1:5 (Table 3). Comparing the ECs of the saturation paste extracts and those of the extract 1:5 (Table 1), it is observed that the ECs determined in the experimental conditions approximate the limit of $4 \mathrm{dS} \mathrm{m} \mathrm{m}^{-1}$, as indicated by Richards (1954) for differentiate between normal and saline soils. In the comparison between soils, the greatest tendency to salinization occurred in soil Inceptisol, with no difference between layers of the same soil (Table 4). This response can be attributed to the EC of the applied residue, much larger than that of the soils sampled (Tables 1 and 2). With similar mineralogy, the two layers of each soil presented the same behavior.

Table 4: Mean orthogonal contrasts (C) of $\mathrm{pH}, \mathrm{EC}(1: 5)$, total $\mathrm{N}, \mathrm{N}-\mathrm{NH}_{4}{ }^{+}, \mathrm{N}-\mathrm{NO}_{3}{ }^{-}, \mathrm{K}, \mathrm{Na}, \mathrm{Ca}$ and $\mathrm{Mg}$ according to the soil and the sampled layer after four leaches with whey ${ }^{(1)}$

\begin{tabular}{lllllllll}
\hline pH & $\begin{array}{l}\mathbf{E C} \\
\mathrm{mS} \mathrm{m}{ }^{-1}\end{array}$ & Total N & ${\mathrm{N}-\mathrm{NH}_{4}{ }^{+}}^{+}$ & $\begin{array}{c}\mathrm{N}^{-\mathrm{NO}_{3}}{ }^{-} \\
\mathrm{mg} \mathrm{dm}^{-3}\end{array}$ & $\mathrm{~K}$ & $\mathrm{Na}$ & $\mathrm{Ca}$ & $\begin{array}{c}\mathrm{Mg} \\
\mathrm{cmol}_{\mathrm{c}} \mathrm{dm}^{-3}\end{array}$ \\
\hline $\mathrm{C} 1$ & $-0.26^{*}$ & $-10.6^{*}$ & $482^{*}$ & $35^{*}$ & 10 & -38 & 7 & $-0.66^{*}$ \\
$\mathrm{C} 2$ & $0.40^{*}$ & 1.0 & $661^{*}$ & $23^{*}$ & -10 & 1 & -19 & $0.85^{*}$ \\
$\mathrm{C} 3$ & $0.76^{*}$ & -0.2 & $992^{*}$ & $57^{*}$ & 4 & 10 & -2 & $1.45^{*}$ \\
\hline
\end{tabular}

1) C1: Oxisol vs Inceptisol. C2: layer 0-20 cm vs layer $20-40 \mathrm{~cm} \mathrm{~d} /$ Oxisol. C3: layer 0-20 cm vs layer 20-40 cm d / Inceptisol. * Significant at $5 \%$ by the $\mathrm{F}$ test.

The EC distribution of extract $1: 5$ is characterized by appreciable leaching of electrolytes along the column (Figure 01). This is confirmed by the values determined at the lower extremities of the columns, always higher than $34.0 \mathrm{mS} \mathrm{m}^{-1}$ (Table 5). The concentration associated with this EC is approximately $3.5 \mathrm{mmol} \mathrm{L}^{-1}$ (RICHARDS, 1954). 
Table 5. Regression equations relating $\mathrm{pH}, \mathrm{EC}(1: 5)$, total $\mathrm{N}, \mathrm{N}-\mathrm{NH}_{4}{ }^{+}, \mathrm{N}-\mathrm{NO}_{3}{ }^{-}, \mathrm{K}, \mathrm{Na}, \mathrm{Ca}$ and $\mathrm{Mg}$, to soil column depth (P) considering the soil and the layer sampled (LS) after four leaches with whey

\begin{tabular}{|c|c|c|c|c|}
\hline Dependent Variable & Soil & LS & Regression Equation & $\mathbf{R}^{2}$ \\
\hline \multirow{5}{*}{$\mathrm{pH}$} & & $\mathrm{cm}$ & & \\
\hline & Oxisol & $0-20$ & $\hat{\mathrm{Y}}=4.986-0.02706 \mathrm{P}+0.0004682 \mathrm{P}^{2}$ & 0.937 \\
\hline & & $20-40$ & $\hat{Y}=4.202+2.344 / \mathrm{P}$ & 0.951 \\
\hline & Inceptisol & $0-20$ & $\hat{\mathrm{Y}}=6.904-0.7653 \mathrm{P}^{0.5}+0.07465 \mathrm{P}$ & 0.887 \\
\hline & & $20-40$ & $\hat{\mathrm{Y}}=10.16-3.99 \mathrm{P}^{0.5}+0.797 \mathrm{P}-0.0484 \mathrm{P}^{1.5}$ & 0.962 \\
\hline \multirow{4}{*}{$\mathrm{EC}\left(\mu \mathrm{S} \mathrm{cm}^{-1}\right)$} & Oxisol & $0-20$ & $\hat{\mathrm{Y}}=1606-261.3 \mathrm{P}^{0.5}+12.66 \mathrm{P}$ & 0.989 \\
\hline & & $20-40$ & $\hat{\mathrm{Y}}=1433-45.62 \mathrm{P}+0.4640 \mathrm{P}^{2}$ & 0.994 \\
\hline & Inceptisol & $0-20$ & $\hat{\mathrm{Y}}=1 /(0.001002+0.00001405 \mathrm{P})$ & 0.955 \\
\hline & & $20-40$ & $\hat{\mathrm{Y}}=630.5+449.4 \mathrm{P}^{0.5}-122.8 \mathrm{P}+7.881 \mathrm{P}^{1.5}$ & 0.992 \\
\hline \multirow{4}{*}{ Total $\mathrm{N}\left(\mathrm{mg} \mathrm{dm}^{-3}\right)$} & Oxisol & $0-20$ & $\hat{\mathrm{Y}}=4159-745.9 \mathrm{P}^{0.5}+57.03 \mathrm{P}$ & 0.984 \\
\hline & & $20-40$ & $\hat{\mathrm{Y}}=995.5+5158 / \mathrm{P}$ & 0.952 \\
\hline & Inceptisol & $0-20$ & $\hat{\mathrm{Y}}=2940-389.1 \mathrm{P}^{0.5}+25.57 \mathrm{P}$ & 0.990 \\
\hline & & $20-40$ & $\hat{\mathrm{Y}}=1962-378.8 \mathrm{P}^{0.5}+23.41 \mathrm{P}$ & 0.965 \\
\hline \multirow[t]{4}{*}{$\mathrm{N}-\mathrm{NH}_{4}{ }^{+}\left(\mathrm{mg} \mathrm{dm}^{-3}\right)$} & Oxisol & $0-20$ & $\hat{\mathrm{Y}}=516.0-129.2 \mathrm{P}^{0.5}+9.843 \mathrm{P}$ & 0.985 \\
\hline & & $20-40$ & $\hat{\mathrm{Y}}=295.9-10.53 \mathrm{P}+0.1159 \mathrm{P}^{2}$ & 0.995 \\
\hline & Inceptisol & $0-20$ & $\hat{\mathrm{Y}}=264.6-40.51 \mathrm{P}^{0.5}+2.315 \mathrm{P}$ & 0.951 \\
\hline & & $20-40$ & $\hat{\mathrm{Y}}=22.58+94.82 \mathrm{P}^{0.5}-26.41 \mathrm{P}+1.861 \mathrm{P}^{1.5}$ & 0.970 \\
\hline \multirow[t]{4}{*}{$\mathrm{N}-\mathrm{NO}_{3}{ }^{-}\left(\mathrm{mg} \mathrm{dm}^{-3}\right)$} & Oxisol & $0-20$ & $\hat{\mathrm{Y}}=1 /(0.008865+0.0002642 \mathrm{P})$ & 0.809 \\
\hline & & $20-40$ & $\hat{\mathrm{Y}}=\overline{\mathrm{Y}}=74$ & \\
\hline & Inceptisol & $0-20$ & $\hat{\mathrm{Y}}=\overline{\bar{Y}}=61$ & \\
\hline & & $20-40$ & $\hat{\mathrm{Y}}=\dot{\bar{Y}}=57$ & \\
\hline \multirow[t]{4}{*}{$\mathrm{K}\left(\mathrm{mg} \mathrm{dm} \mathrm{m}^{-3}\right)$} & Oxisol & $0-20$ & $\hat{\mathrm{Y}}=2573-599.9 \mathrm{P}^{0.5}+37.42 \mathrm{P}$ & 0.994 \\
\hline & & $20-40$ & $\hat{\mathrm{Y}}=1832-70.23 \mathrm{P}+0.7182 \mathrm{P}^{2}$ & 0.989 \\
\hline & Inceptisol & $0-20$ & $\hat{\mathrm{Y}}=1331-34.12 \mathrm{P}+0.2686 \mathrm{P}^{2}$ & 0.994 \\
\hline & & $20-40$ & $\hat{\mathrm{Y}}=1997-365.3 \mathrm{P}^{0.5}+17.24 \mathrm{P}$ & 0.988 \\
\hline \multirow[t]{4}{*}{$\mathrm{Na}\left(\mathrm{mg} \mathrm{dm}^{-3}\right)$} & Oxisol & $0-20$ & $\hat{\mathrm{Y}}=387.4-55.89 \mathrm{P}^{0.5}+1.653 \mathrm{P}$ & 0.976 \\
\hline & & $20-40$ & $\hat{\mathrm{Y}}=572.2-127.1 \mathrm{P}^{0.5}+8.381 \mathrm{P}$ & 0.974 \\
\hline & Inceptisol & $0-20$ & $\hat{\mathrm{Y}}=1 /(0.003677+0.0001268 \mathrm{P})$ & 0.966 \\
\hline & & $20-40$ & $\hat{\mathrm{Y}}=211.8-2.094 \mathrm{P}$ & 0.970 \\
\hline \multirow[t]{4}{*}{$\mathrm{Ca}\left(\mathrm{cmol}_{\mathrm{c}} \mathrm{dm}^{-3}\right)$} & Oxisol & $0-20$ & $\hat{\mathrm{Y}}=\overline{\mathrm{Y}}=1.87$ & \\
\hline & & $20-40$ & $\hat{\mathrm{Y}}=3.674-0.9037 \mathrm{P}^{0.5}+0.06822 \mathrm{P}$ & 0.996 \\
\hline & Inceptisol & $0-20$ & $\hat{\mathrm{Y}}=2.256+0.01833 \mathrm{P}$ & 0.910 \\
\hline & & $20-40$ & $\hat{\mathrm{Y}}=2.001-0.3565 \mathrm{P}^{0.5}+0.04052 \mathrm{P}$ & 0.825 \\
\hline \multirow[t]{4}{*}{$\operatorname{Mg}\left(\mathrm{cmol}_{\mathrm{c}} \mathrm{dm}^{-3}\right)$} & Oxisol & $0-20$ & $\hat{\mathrm{Y}}=0.5220+0.009024 \mathrm{P}$ & 0.981 \\
\hline & & $20-40$ & $\hat{\mathrm{Y}}=0.8355-0.1942 \mathrm{P}^{0.5}+0.01623 \mathrm{P}$ & 0.980 \\
\hline & Inceptisol & $0-20$ & $\hat{\mathrm{Y}}=0.5987+0.01508 \mathrm{P}$ & 0.970 \\
\hline & & $20-40$ & $\hat{\mathrm{Y}}=0.5087-0.09540 \mathrm{P}^{0.5}+0.01741 \mathrm{P}$ & 0.942 \\
\hline
\end{tabular}




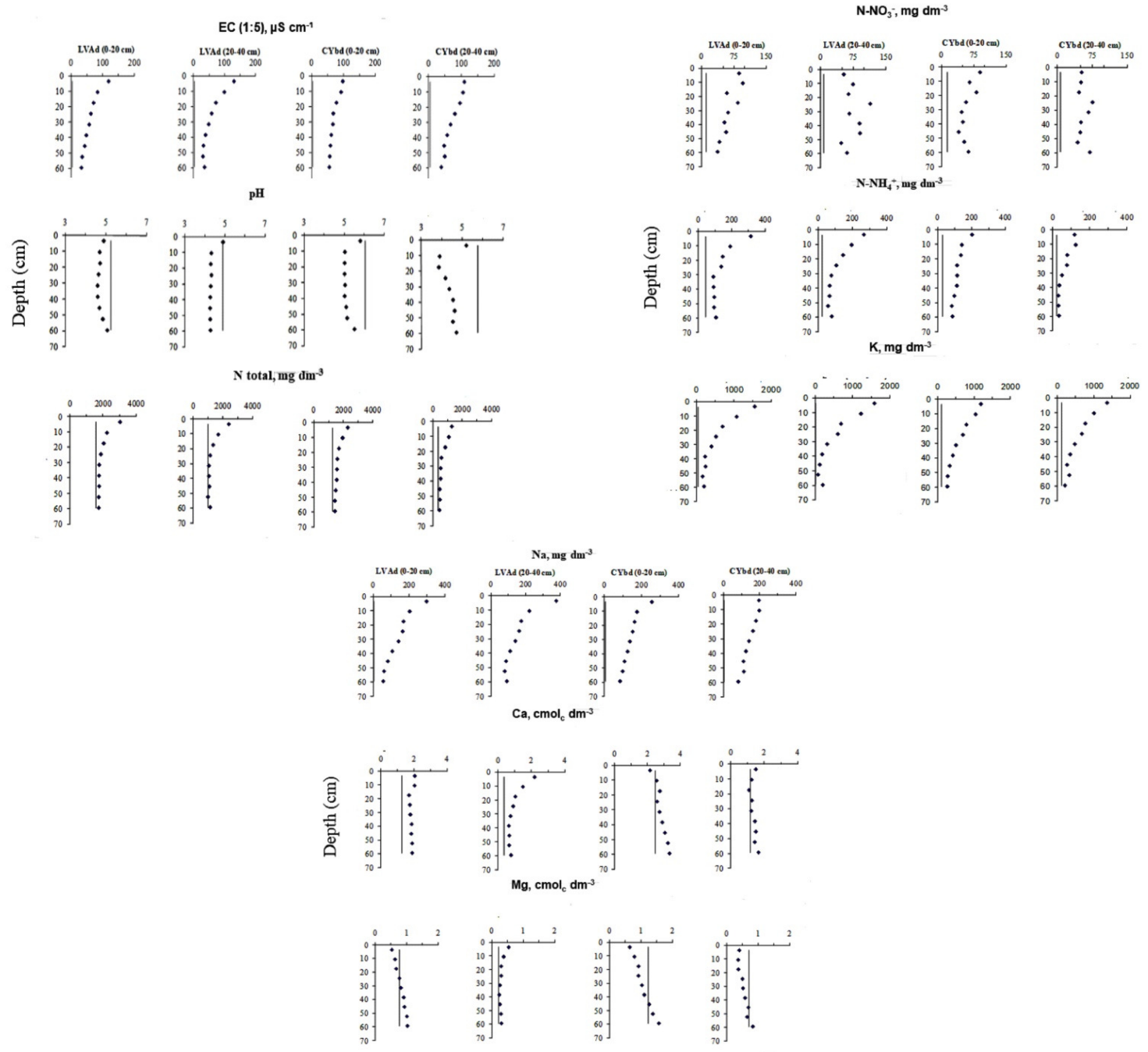

Figure 1. In-depth behavior of: $\mathrm{pH}, \mathrm{EC}(1: 5)$, Total $\mathrm{N}, \mathrm{N}^{-\mathrm{NO}_{3}}{ }^{-}, \mathrm{N}^{-\mathrm{NH}_{4}}{ }^{+}, \mathrm{K}, \mathrm{Na}, \mathrm{Ca}$ and $\mathrm{Mg}$ considering the soil class and the sampling depth. The vertical dash indicates the value in the preliminary characterization of the soil.

Considering the nitrogen compounds (total $\mathrm{N}, \mathrm{NH}_{4}^{+}$and $\mathrm{NO}_{3}^{-}$), it was verified that, in all cases, the application of whey caused the increase of their availability (Tables 1 and 3). However, the total $\mathrm{N}$ ratio: $\mathrm{N}-\mathrm{NH}_{4}^{+}: \mathrm{N}^{-} \mathrm{NO}_{3}^{-}$presented particularities
(Table 6). There was a higher increase in assimilable $\mathrm{N}\left(\mathrm{N}-\mathrm{NH}_{4}{ }^{+}\right.$and $\left.\mathrm{N}-\mathrm{NO}_{3}{ }^{-}\right)$due to the mineralization processes of the organic matter and the higher concentration of these forms in relation to organic $\mathrm{N}$ from the incorporated whey (Table 2).

Table 6. Total N ratio: $\mathrm{N}-\mathrm{NH}_{4}^{+}: \mathrm{N}-\mathrm{NO}^{3-}$ in the soil (in the characterization and after four leaching) and applied whey

\begin{tabular}{|c|c|c|c|c|}
\hline \multirow{2}{*}{ Material } & \multicolumn{2}{|c|}{ Oxisol } & \multicolumn{2}{|c|}{ Inceptisol } \\
\hline & $0-20 \mathrm{~cm}$ & $20-40 \mathrm{~cm}$ & $0-20 \mathrm{~cm}$ & $20-40 \mathrm{~cm}$ \\
\hline \multicolumn{5}{|c|}{ Soil } \\
\hline In the characterization & $142.5: 3.9: 1$ & $138.4: 3.0: 1$ & $87.9: 2.0: 1$ & $53.5: 3.0: 1$ \\
\hline After leaching & $31.2: 2.2: 1$ & $18.1: 1.6: 1$ & $27.6: 2.0: 1$ & $12.1: 1.2: 1$ \\
\hline \multicolumn{5}{|c|}{ Whey } \\
\hline \multicolumn{5}{|c|}{$17,9: 3: 1$} \\
\hline
\end{tabular}


There were statistically significant differences for total $\mathrm{N}$ and $\mathrm{N}-\mathrm{NH}_{4}{ }^{+}$between soils and between layers within each soil. The greatest increase was in Oxisol and in the upper layers within each soil. The lower levels of $\mathrm{N}^{-\mathrm{NO}_{3}}{ }^{-}$and the lower interaction with the soil ion exchange complex did not show statistically significant differences for this element in the analyzed contrasts (Table 4).

Soil chemical analysis revealed decreases in total $\mathrm{N}, \mathrm{N}-\mathrm{NH}_{4}{ }^{+}$and $\mathrm{N}^{-\mathrm{NO}_{3}}{ }^{-}$after application of whey (Table 3 ). Similar results were found by Gheri et al. (2003), when applying whey on samples of a Red-Yellow Argisol in a degraded pasture area. According to these authors, despite the high doses of $\mathrm{N}$ provided to the soil with the application of this residue, there was no significant increase in total $\mathrm{N}$. This fact indicates that the mineralization rate of $\mathrm{N}$ compounds was sufficiently fast that they did not allow accumulation of these compounds in the soil.

Considering the mobility and distribution of the nitrogen compounds along the column, the total $\mathrm{N}$ applied, composed of a maximum of $18 \%$ of $\mathrm{N}$ $\mathrm{NH}_{4}^{+}+\mathrm{N}^{+} \mathrm{NO}_{3}^{-}$(Table 3), the remainder being bound to organic molecules of higher molecular weight and, possibly, lower solubility, recorded appreciable transport up to approximately half of the column (Figure 01). The $\mathrm{NH}_{4}{ }^{+}$, interacting with the cation exchange complex of the soil, moved along the column, but with higher availability in the upper portion (Figure 01). $\mathrm{NO}_{3}{ }^{-}$was the most mobile nitrogen compound, due to its higher solubility and lower interaction with the soil particles (Figure 01). Of all the ions studied, it was the only one that did not have adequate adjustment in the regression analysis (Figure 01 and Table 5).

Considering the alkaline and alkaline-earth cations, there is also a general increase in the levels of $\mathrm{K}, \mathrm{Na}, \mathrm{Ca}$ and $\mathrm{Mg}$ in the soil after application of whey, in relation to the values determined in the characterization (Tables 1, 3 and Figure 01). However, only statistically significant differences were recorded for $\mathrm{Ca}$ and $\mathrm{Mg}$ in both the comparison between soils and in the comparison between layers (Table 4). It is observed that the whey had high concentrations of $\mathrm{K}$ and $\mathrm{Na}$ (Table 2 ), being found in a lower concentration in the exchange complex, as shown in the soil characterization (Table 1). The characteristic of the displacing fluid led to the $\mathrm{Na}$ and $\mathrm{K}$ levels close to those of the soil characterization after the four applications, considering that their textural and mineralogical characteristics are similar (Table 1 and 4).

In order to allow comparison, the available $\mathrm{K}$ and $\mathrm{Na}$ contents and exchangeable $\mathrm{Ca}$ and $\mathrm{Mg}$ in the previous and subsequent soil leaching characterization (Tables 1 and 3), as well as the concentration of these same elements in the whey (Table 2), were recalculated and their values expressed in $\mathrm{cmol}_{\mathrm{c}} \mathrm{dm}^{-3}$ and $\mathrm{cmol}_{\mathrm{c}} \mathrm{L}^{-1}$, respectively (Table 7). The K: Na: Ca: $\mathrm{Mg}$ ratios thus calculated allow us to advance in the discussion of the topic.

Table 7. Levels of $\mathrm{K}, \mathrm{Na}, \mathrm{Ca}$ and $\mathrm{Mg}$ in the soil (in the characterization and after four leaches) and applied whey

\begin{tabular}{|c|c|c|c|c|c|}
\hline Material & $\mathbf{K}$ & $\mathbf{N a}$ & $\mathbf{C a}$ & Mg & K:Na:Ca:Mg \\
\hline \multicolumn{6}{|c|}{ Solo in the characterization $\left(\mathrm{cmol}_{\mathrm{c}} \mathrm{dm}^{-3}\right)$} \\
\hline Oxisol $(0-20 \mathrm{~cm})$ & 0.14 & 0.02 & 1.30 & 0.77 & $0.18: 0.03: 1.69: 1$ \\
\hline Oxisol $(20-40 \mathrm{~cm})$ & 0.04 & 0.01 & 0.38 & 0.22 & $0.18: 0.05: 1.73: 1$ \\
\hline Inceptisol $(0-20 \mathrm{~cm})$ & 0.27 & 0.02 & 2.47 & 1.23 & $0.22: 0.02: 2.01: 1$ \\
\hline Inceptisol $(20-40 \mathrm{~cm})$ & 0.29 & 0.02 & 1.18 & 0.71 & $0.41: 0.03: 1.66: 1$ \\
\hline \multicolumn{6}{|c|}{ Soil after leaching $\left(\mathrm{cmol}_{\mathrm{c}} \mathrm{dm}^{-3}\right)$} \\
\hline Oxisol $(0-20 \mathrm{~cm})$ & 1.46 & 0.62 & 1.87 & 0.81 & $1.80: 0.77: 2.31: 1$ \\
\hline Oxisol $(20-40 \mathrm{~cm})$ & 1.45 & 0.70 & 1.03 & 0.32 & $4.53: 2.19: 3.22: 1$ \\
\hline Inceptisol $(0-20 \mathrm{~cm})$ & 1.57 & 0.63 & 2.83 & 1.07 & $1.47: 0.59: 2.64: 1$ \\
\hline Inceptisol $(20-40 \mathrm{~cm})$ & 1.54 & 0.63 & 1.38 & 0.55 & $2.80: 1.15: 2.51: 1$ \\
\hline \multicolumn{6}{|c|}{ Whey $\left(\mathrm{cmol}_{\mathrm{c}} \mathrm{L}^{-1}\right)$} \\
\hline & 4.25 & 1.98 & 2.78 & 0.63 & $6.79: 3.17: 4.44: 1$ \\
\hline
\end{tabular}

The Ca:Mg ratio, with extremes of 1.69 and 2.01:1 in the soil before the assay was increased to 2.31 and the range 3.22:1 after leaching. From the nutritional point of view, the application of whey, therefore, would not cause imbalance of these two nutrients, considering that its $\mathrm{Ca}: \mathrm{Mg}$ ratio is $4.44: 1$ (Table 7).

Greater attention should be considered regarding $\mathrm{K}$ and especially $\mathrm{Na}$. Taking the $\mathrm{Mg}$ as a reference, $\mathrm{K}$ values between 0.18 and $0.41: 1$ rose up to $4.53: 1$. Na, close to $0.03: 1$ in all cases, increased 
to $2.19: 1$ in the Oxisol, sampled between 20 and 40 $\mathrm{cm}$ (Table 7). The Na:Mg ratios were higher in the deeper layers of both soils, indicating greater susceptibility to salinization in samples with lower organic matter content.

As verified by the high ECs in the soil after the application of the whey, it was evidenced the tendency of salinization of these soils with the increase of the whey volume applied. The $\mathrm{Na}: \mathrm{Mg}$ ratio of this milk residue, 3.14:1, reinforces the need for careful use. On the other hand, the ratio $\mathrm{K}$ : Na: $\mathrm{Ca}: \mathrm{Mg}$ of whey, 6.75: 3.14: 4.41: 1, indicates the possibility of loss of $\mathrm{Mg}$ by leaching, by displacement of this nutrient from the exchange, due to the high concentrations of $\mathrm{K}, \mathrm{Na}$ and $\mathrm{Ca}$ (Table 7).

Comparing the transport of $\mathrm{K}, \mathrm{Na}, \mathrm{Ca}$ and $\mathrm{Mg}$ in the columns (Figure 01), it is observed that the high concentrations of $\mathrm{K}, \mathrm{Na}$ and $\mathrm{Ca}$ (Table 3) caused $\mathrm{Mg}$ displacement of the exchange complex and marked leaching. This is proved by the equation of the curves of this cation (Figure 01) where concentrations lower than those of the characterization in the upper portion of the columns were determined. This response is less visualized for $\mathrm{Ca}$ (Figure 01) because of its higher concentration in whey (Table 2) and the greater interaction with the cation exchange complex of the soil.

Only the first two percolates collected after 24 hours of the application of the whey were analyzed because of the difficulty in the leaching caused by the accumulation of suspended and fat materials, mainly in the upper part of the columns, as previously indicated. Also, in the fourth application of the whey, some columns received inferior volumes than proposed, as a function of the decrease of the infiltration. The application of $20 \%$ of the pore volume of whey may have caused organic overload and surface sealing because it was carried out in a reduced time interval (6 days between applications), leading to a decrease in the hydraulic conductivity and a consequent decrease in leached volume (Table 8). This fact indicates that, although there was an increase in microbial activity, a more adequate whey management would be necessary. In this sense, field trials would be satisfactory to prove that longer intervals between applications or whey dilution, if economically feasible, could increase the volume of collected leachate, thus alleviating problems related to low hydraulic conductivity.

Table 8. Volume of the leachate after 24 and 120 hours of application of 0.2 volume of whey pores, according to the soil and the sampled layer. Values in parentheses indicate proportion of the volume leached relative to the volume applied in each leach.

\begin{tabular}{|c|c|c|c|c|}
\hline \multirow{2}{*}{ Volume } & \multicolumn{2}{|c|}{ Oxisol } & \multicolumn{2}{|c|}{ Inceptisol } \\
\hline & 0-20 cm & $20-40 \mathrm{~cm}$ & $0-20 \mathrm{~cm}$ & $20-40 \mathrm{~cm}$ \\
\hline \multirow{3}{*}{ Applied } & & $\mathrm{m}$ & & \\
\hline & 296 & 312 & 305 & 315 \\
\hline & \multicolumn{4}{|c|}{ First leaching } \\
\hline Leached 0-24 h & $235(0.794)$ & $243(0.778)$ & $241(0.790)$ & $231(0.733)$ \\
\hline Leached $24-120 \mathrm{~h}$ & $20(0.068)$ & $35(0.112)$ & $28(0.092)$ & $55(0.175)$ \\
\hline \multirow[t]{2}{*}{ Leached total } & $255(0.862)$ & $278(0.890)$ & $269(0.882)$ & $286(0.908)$ \\
\hline & \multicolumn{4}{|c|}{ Second leaching ${ }^{(1)}$} \\
\hline Leached $0-24 \mathrm{~h}$ & $215(0.727)$ & $178(0.571)$ & $186(0.610)$ & $232(0.737)$ \\
\hline Leached $24-120 \mathrm{~h}$ & $23(0.078)$ & $19(0.061)$ & $20(0.066)$ & $31(0.098)$ \\
\hline \multirow[t]{2}{*}{ Leached total } & $238(0.805)$ & $197(0.631)$ & $206(0.675)$ & $263(0.835)$ \\
\hline & \multicolumn{4}{|c|}{ Third leaching ${ }^{(1)}$} \\
\hline Leached $0-24 \mathrm{~h}$ & $78(0.264)$ & $105(0.337)$ & $180(0.590)$ & $188(0.597)$ \\
\hline Leached $24-120 \mathrm{~h}$ & $29(0.098)$ & $28(0.090)$ & $25(0.082)$ & $27(0.086)$ \\
\hline \multirow[t]{2}{*}{ Leached total } & $107(0.362)$ & $133(0.426)$ & $205(0.672)$ & $215(0.683)$ \\
\hline & \multicolumn{4}{|c|}{ Fourth leaching ${ }^{(1) .(2)}$} \\
\hline Leached 0-24 h & $46(<0.156)$ & $100(<0.321)$ & $142(<0.466)$ & $133(<0.422)$ \\
\hline Leached $24-120 \mathrm{~h}$ & $37(<0.125)$ & $44(<0.141)$ & $32(<0.105)$ & $29(<0.092)$ \\
\hline Leached total & $83(<0.281)$ & $144(<0.462)$ & $174(<0.570)$ & $162(<0.514)$ \\
\hline
\end{tabular}

(1) Interval between leaching: 144 hours. (2) Some columns, in this leaching, received volumes lower than indicated, due to the decrease of infiltration.

The determinations carried out in the percolates included $\mathrm{pH}, \mathrm{EC}, \mathrm{COD}$, total $\mathrm{N}, \mathrm{N}^{-\mathrm{NH}_{4}}{ }^{+}$,
$\mathrm{N}-\mathrm{NO}_{3}{ }^{-}, \mathrm{K}, \mathrm{Na}, \mathrm{Ca}$ and $\mathrm{Mg}$. Values different from seven for $\mathrm{pH}$ and zero in other determinations 
indicate that in all cases there was a leaching of solutes that contributed by the whey and possibly displaced from the soil exchange complex. In the comparison between soils and layers, larger losses of solutes in the Inceptisol and the $0-20 \mathrm{~cm}$ layer are observed in general, compared to the samples taken at $20-40 \mathrm{~cm}$. In leachates there was, in general, a decrease in $\mathrm{pH}$ and an increase in solute loss in the second leaching, compared to the first one (Table 9).

Table 9. Mean orthogonal contrasts (C) of $\mathrm{pH}, \mathrm{COD}$ and total $\mathrm{N}, \mathrm{N}-\mathrm{NH}_{4}{ }^{+}, \mathrm{N}_{-} \mathrm{NO}_{3}{ }^{-}, \mathrm{K}, \mathrm{Na}, \mathrm{Ca}$ and $\mathrm{Mg}$ in the effluent collected in 24 hours in the first two leaches, according to the soil and the sampled layer ${ }^{(1)}$

\begin{tabular}{|c|c|c|c|c|c|c|c|}
\hline Determination & C1 & $\mathrm{C2}$ & $\mathrm{C3}$ & $\mathrm{C4}$ & C5 & C6 & C7 \\
\hline $\mathrm{pH}$ & -0.73 & -0.88 & -0.345 & 0.55 & -0.51 & 1.58 & 0.90 \\
\hline $\mathrm{EC}\left(\mathrm{dS} \mathrm{m} \mathrm{m}^{-1}\right)$ & -0.35 & 1.03 & 1.58 & -0.69 & -0.050 & -1.26 & -0.16 \\
\hline $\mathrm{COD}\left(\mathrm{mg} \mathrm{L}^{-1}\right)$ & -514 & 2442 & 3058 & -2152 & -460 & 1865 & 1035 \\
\hline Total N (mg/column) & 1.64 & 9.89 & 11.55 & -5.95 & -2.93 & -3.58 & -0.41 \\
\hline $\mathrm{N}^{-\mathrm{NH}_{4}}{ }^{+}$(mg/column $)$ & 0.97 & 8.43 & 9.16 & -3.81 & 0.51 & -0.78 & 0.25 \\
\hline $\mathrm{N}^{-\mathrm{NO}_{3}}{ }^{-}(\mathrm{mg} /$ column $)$ & 0.036 & -0.62 & 0.20 & -0.20 & -0.82 & 0.56 & 0.21 \\
\hline $\mathrm{K}$ (mg/column) & $\mathrm{VNH}^{2 /}$ & 5.51 & 4.18 & -0.77 & 0.03 & -0.85 & -2.76 \\
\hline $\mathrm{Na}$ (mg/column) & -0.54 & 1.81 & 1.26 & 1.70 & -0.19 & -1.01 & -0.95 \\
\hline $\mathrm{Ca}$ (mg/column) & -12.35 & 20.20 & 41.47 & -10.79 & -0.35 & -42.09 & -2.52 \\
\hline $\operatorname{Mg}$ (mg/column) & $\mathrm{VNH}^{(2)}$ & 10.81 & 10.36 & -5.70 & 0.21 & 1.45 & -1.39 \\
\hline
\end{tabular}

Table 10 shows the relationships between total $\mathrm{N}, \mathrm{N}-\mathrm{NH}_{4}{ }^{+}$and $\mathrm{N}-\mathrm{NO}_{3}{ }^{-}$determined for each soil, sampling depth and leaching. It is observed that, independently of the treatment, the sum of $\mathrm{N}$ $\mathrm{NH}_{4}{ }^{+}$and $\mathrm{N}^{-\mathrm{NO}_{3}}{ }^{-}$is almost equal to the concentration of total $\mathrm{N}$, revealing that organic nitrogen was almost totally degraded. Any differences should be attributed to the method of determination. Thus, other nitrogenous compounds were practically not lost by leaching in the columns. The loss of $\mathrm{N}$ in its most soluble forms should be taken into consideration when applying whey, due to the potential of this residue.

Table 10. Total $\mathrm{N}$ ratio: $\mathrm{N}_{-\mathrm{NH}_{4}}^{+}$and $\mathrm{N}^{-\mathrm{NO}_{3}}{ }^{-}$in the effluent collected in 24 hours in the first and second leaches, according to the soil and the sampled layer

\begin{tabular}{lccccc}
\hline \multirow{2}{*}{ Leaching } & \multicolumn{2}{c}{ Oxisol } & & \multicolumn{2}{c}{ Inceptisol } \\
\cline { 2 - 3 } \cline { 5 - 6 } & $\mathbf{0 - 2 0} \mathbf{~ c m}$ & $\mathbf{2 0 - 4 0} \mathbf{~ c m}$ & & $\mathbf{0 - 2 0} \mathbf{~ c m}$ & $\mathbf{2 0 - 4 0 ~ c m ~}$ \\
\hline First & $10.3: 8.2: 1$ & & $6.3: 5.7: 1$ & $1.3: 0.99: 1$ \\
Second & $13.1: 9.7: 1$ & $2.7: 1.1: 1$ & & $11.7: 8.2: 1$ & $1.9: 0.96: 1$ \\
\hline
\end{tabular}

To compare the amount of leached $\mathrm{K}$, Na, $\mathrm{Ca}$ and $\mathrm{Mg}$, were transformed to $\mathrm{mmol}_{\mathrm{c}}$, and concentrations were calculated by dividing the amounts by the leached volume (Table 8 ). The results, together with those from whey characterization (Table 2), all expressed as $\mathrm{mmol}_{\mathrm{c}} \mathrm{L}^{-}$ ${ }^{1}$, are shown in Table 11.

In the characterization of whey, the concentration sequence is: $\mathrm{K}>\mathrm{Ca}>\mathrm{Na}>\mathrm{Mg}$. In the set of leachates, $\mathrm{Ca}>\mathrm{Mg}>\mathrm{K}>\mathrm{Na}$.
There are two changes in this sequence when exchanging $\mathrm{Na}$ and $\mathrm{K}$ position, but without appreciably altering the general trend, ie $\mathrm{Ca}>\mathrm{Mg}$ and $\mathrm{K}>\mathrm{Na}$. The distribution of $\mathrm{K}, \mathrm{Na}, \mathrm{Ca}$ and $\mathrm{Mg}$ in the soil columns (Figure 01) shows a distinct trend in the distribution of these cations, with a higher surface concentration for $\mathrm{K}$ and $\mathrm{Na}$. The $\mathrm{Ca}$ shows little change in depth in the Oxisol, even considering that the added residue is rich in $\mathrm{Ca}$. In 
the Inceptisol there is a clear trend of leaching loss. The same can be indicated for $\mathrm{Mg}$.

From the comparison between the values of Tables 11 and Figure 01, it was concluded that K, in higher concentration in the whey, but with greater interaction with the soil particles, was proportionally less leached than $\mathrm{Na}$, found in very low availability in soils and layers in study (Table
1). The two monovalent cations contribute to the displacement of $\mathrm{Ca}$ and $\mathrm{Mg}$ - the latter in a higher proportion, due to lower concentration in the applied whey and less interaction with the cation exchange complex of the soil.

Table 11. Concentration of $\mathrm{K}, \mathrm{Na}, \mathrm{Ca}$ and $\mathrm{Mg}$ in whey and effluent collected in 24 hours in the first and second leaches, according to the soil and the sampled layer

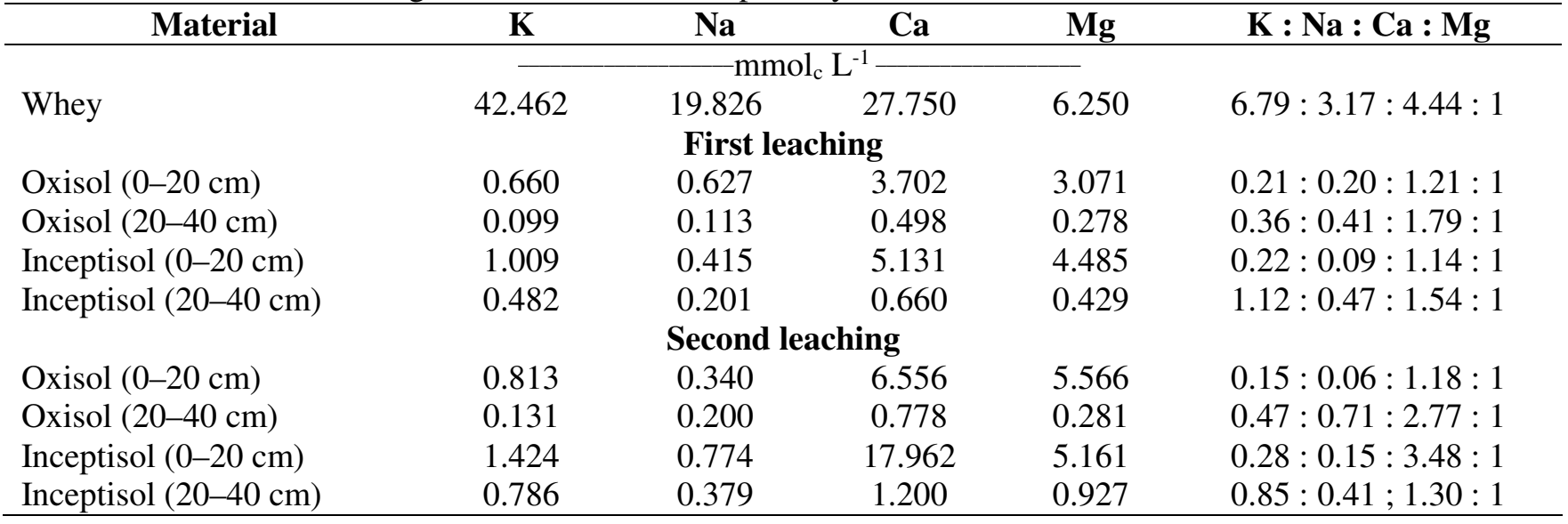

\section{CONCLUSIONS}

The application of whey in the soil as the final destination for this residue is an environmentally viable alternative, provided that a correct management is made in order to avoid problems of surface sealing, salinization and leaching of undesirable elements.

The high electrolyte concentrations of whey caused a general increase of EC in the studied soils, suggesting a tendency to salinization.
There was a higher increase in the assimilable nitrogen content $\left(\mathrm{N}-\mathrm{NH}_{4}{ }^{+}\right.$and $\left.\mathrm{N}-\mathrm{NO}_{3}{ }^{-}\right)$ in the soil due to the mineralization processes of the organic matter and the higher concentration of these forms in relation to the total $\mathrm{N}$ in the whey.

High concentrations of $\mathrm{K}, \mathrm{Na}$ and $\mathrm{Ca}$ caused $\mathrm{Mg}$ displacement of the exchange complex and marked leaching of this nutrient.

The Na: Mg ratio of 3.14: 1 in the whey reinforces the need for careful disposal of this effluent in the soil.

RESUMO: Entre os setores da indústria alimentícia, o segmento de laticínios é um dos mais importantes do Brasil, sendo o soro de leite o seu maior subproduto. Devido às dificuldades de reaproveitamento e aos impactos ambientais causados, quando descartado como efluente em corpos de água, uma alternativa para a sua destinação final seria a aplicação desse resíduo no solo. Objetivou-se com este trabalho determinar alterações químicas e a mobilidade e distribuição de solutos no solo após aplicação fracionada de soro de leite, assim como a caracterização dos percolados recolhidos após cada aplicação. O ensaio, em laboratório, foi conduzido em colunas de PVC preenchidas com solo. Os tratamentos corresponderam a um fatorial 2 x 2, sendo amostras de um Latossolo Vermelho-Amarelo distrófico típico (LVAd) e de um Cambissolo Flúvico Tb distrófico (CYbd), coletados em duas profundidades: 0-20 e 20-40 cm. Cada unidade experimental foi constituída de 11 anéis de PVC, com 6,6 cm de diâmetro interno e $7 \mathrm{~cm}$ de altura. As colunas foram dispostas em um delineamento experimental em blocos casualizados, com cinco repetições. Foram realizadas quatro aplicações de soro de leite, correspondentes a 0,2 volume de poros de solo, a cada intervalo de seis dias. O percolado foi recolhido após 24 e 120 horas de cada aplicação sendo realizadas as seguintes determinações: $\mathrm{pH}$, condutividade elétrica (CE), demanda química de oxigênio (DQO), teores de $\mathrm{N}$ total, $\mathrm{N}^{-\mathrm{NH}_{4}}{ }^{+}, \mathrm{N}-\mathrm{NO}_{3}{ }^{-}, \mathrm{Na}, \mathrm{K}, \mathrm{Ca}$ e $\mathrm{Mg}$. Após seis dias da última aplicação de soro de leite, as colunas foram desmontadas e o solo de cada anel analisado. As análises compreenderam: $\mathrm{pH}$ em água, $\mathrm{CE}(1: 5), \mathrm{N}$ total, $\mathrm{N}^{-\mathrm{NH}_{4}}{ }^{+}, \mathrm{N}^{-\mathrm{NO}_{3}}{ }^{-}, \mathrm{Na}, \mathrm{K}, \mathrm{Ca}$ e $\mathrm{Mg}$. As elevadas 
concentrações eletrolíticas do soro de leite provocaram aumento generalizado da CE no solo. Houve incremento maior do nitrogênio assimilável $\left(\mathrm{N}^{-\mathrm{NH}_{4}}{ }^{+}\right.$e $\left.\mathrm{N}^{-\mathrm{NO}_{3}}{ }^{-}\right)$no solo em decorrência de processos de mineralização. Elevadas concentrações de $\mathrm{K}, \mathrm{Na}$ e $\mathrm{Ca}$ causaram deslocamento de $\mathrm{Mg}$ do complexo de troca. Conclui-se que a aplicação de soro de leite no solo é uma alternativa viável do ponto de vista ambiental, desde que seja feito um correto manejo, a fim de evitar problemas de salinização e perdas por lixiviação de elementos indesejáveis.

PALAVRAS-CHAVES: Mineralização de nitrogênio. Lixiviação. Salinização.

\section{REFERENCES}

ALVAREZ V., V. H.; NOVAIS, R. F.; DIAS, L. E.; OLIVEIRA, J. A. Determinação e uso do fósforo remanescente. Boletim Informativo da SBCS, v. 25, n. 1, p. 27-33, 2000.

ALVAREZ V., V. H.; ALVAREZ, G. A. M. Comparação de médias ou teste de hipóteses? Contrastes! Boletim Informativo da SBCS, v. 31, n. 4, p. 24-34, 2006.

APHA - AMERICAN PUBLIC HEALTH ASSOCIATION. Standard methods for the examination of water and wastewater. 19.ed. Washington, American Public Health Association, American Water Works Association, Water Pollution Control Federation, 1995. s.p.

ARAÚJO, E. H. Redução na poluição dos laticínios pela transformação da lactose do soro de queijo em etanol. In: CONGRESSO BRASILEIRO DE ENSINO DE ENGENHARIA, 39., Porto Alegre, 2001. Anais... Porto Alegre, Associação Brasileira de Educação em Engenharia, 2001. p.1-6.

BERTOL, T. M.; GOMES, J. D. F.; SILVA, E. D. Soro de leite integral na alimentação de suínos em crescimento e terminação. Revista da Sociedade Brasileira de Zootécnica, Viçosa, v. 22, n. 6, p. 993-1002, 1993.

BOUNOUS, G; GERVAIS, F; AMER, V; BATIST, G; GOLD,P. The influence of dietary whey protein on tissue glutathione and the diseases of aging. Clinical and Investigative Medicine, n. 12, p. 343-349, 1989

BRAGA, J. M.; DEFELIPO, B. V. Determinação espectrofotométrica do fósforo em extratos de solos e plantas. Revista Ceres, Viçosa, v. 21, n. 113 p. 73-85, 1974.

BRANDÃO, S. C. C. Soro: Um desafio para as fábricas de queijo. Revista Leite \& Derivados, Belo Horizonte, v. 15, n. 1 p. 13-19, 1994.

BRASIL. Ministério da Agricultura, Pecuária e Abastecimento (MAPA). Estabelece os padrões de identidade e qualidade de soro de leite. Instrução Normativa nº 53, 25 de agosto de 2013.

DEFELIPO, B. V.; RIBEIRO, A. C. Análise química do solo. 2.ed. Viçosa: Editora UFV, 1997. 26p. (Boletim de Extensão, 29)

GHERI, E. O.; FERREIRA, M. E.; CRUZ, M. C. P. Resposta do capim-tanzânia à aplicação de soro ácido de leite. Pesquisa Agropecuária Brasileira Brasília, v. 38, n. 6, p.753-760, 2003. https://doi.org/10.1590/S0100204X2003000600012

LIZIEIRE, R. S; CAMPOS, O. F. Soro de queijo "in nautra" na alimentação do gado de leite. Niterói, Empresa de Pesquisa Agropecuária do Rio de Janeiro e Embrapa Gado de Leite, 2001. (Instrução Técnica para o Produtor de Leite, 44)

MACHADO, R. M. G.; SILVA, P. C.; FREIRE, V. H. Controle Ambiental em indústrias de laticínios. Brasil Alimentos, Março/Abril, p. 34-36, 2001 
MAHMOUD, MI. Physicochemical and functional properties of protein hydrolysates in nutritional products. Food Technology, v. 48, p. 89-113, 1994.

RICHARDS, L. A. Diagnosis and improvement of saline and alkali soils. Washington DC, U.S. Departament of Agriculture, 1954. 160 p. (USDA Agricultural Handbook, 60)

ROBBINS, C. W.; LEHRSCH, G. A. Cheese whey as a soil conditioner. In: WALLACE, A.; TERRY, R., ed. Handbook of soil conditioners: Substances that enhance the physical properties of soil. 1.ed. New York, Marcel Dekker, INC, 1998. p.167-185.

ROLFS, A. L. B; BACCAR, N. M.; OLIVEIRA, M. S. R.; MARQUARTD, L.; RICHARDS, N. S. P. S. Indústrias lácteas: alternativas de aproveitamento do soro de leite como forma de gestão ambiental. TecnoLógica, Santa, v. 15, n. 2, p. 79-83,. 2011.

RUIZ, H. A. Incremento da exatidão da análise granulométrica do solo por meio da coleta da suspensão (silte + argila). Revista Brasileira de Ciências do Solo. Viçosa, v. 29, n. 2, p. 297-300, 2005.

https://doi.org/10.1590/S0100-06832005000200015

SANTOS, J. P. V.; FERREIRA, C. L. L. F. Alternativas para o aproveitamento de soro de queijo nos pequenos e médios laticínios. Revista do Instituto de Laticínios Cândido Tostes, Juiz de Fora, v. 56, n. 321, p. 44-50, 2001.

SILVA, D. J. P. Diagnóstico do consumo de água e da geração de efluentes em uma indústria de laticínios e desenvolvimento de um sistema multimídia de apoio. 2006, 88p. Dissertação de Mestrado (Mestrado em Tecnologia de Alimentos). Programa de Pós Graduação em Ciência e Tecnologia de Alimentos. Universidade Federal de Viçosa, Viçosa, 2006.

TEDESCO, M. J., GIANELLO, C., BISSANI, C. A., BOHEN, H.; VOLKWEISS, S. J. Análises de solos, plantas e outros materiais. 2.ed. Porto Alegre, Departamento de Solos, UFRGS, 1995. 174p. (Boletim Técnico de Solos, 5)

VETTORI, L. Métodos de análise de solo. Rio de Janeiro: Equipe de Pedologia e Fertilidade do Solo, Ministério da Agricultura, 1969. 24p. (Boletim Técnico, 7) 